\title{
Relationship of Temperature Based Meteorological Indices with Phenology and Yield Performance of Wheat as Influenced by Sowing Times
}

\author{
Bhagat Singh, Mukesh Kumar* and A.K. Dhaka \\ Department of Agronomy, CCS Haryana Agricultural University, Hisar-125004, India \\ *Corresponding author
}

\begin{tabular}{|l|}
\hline Ke y w o r d s \\
Late sown wheat, \\
GDD, PTU, HTU, \\
PTI, HUE, Grain \\
yield \\
\hline Article Info \\
\hline $\begin{array}{l}\text { Accepted: } \\
\text { 04 February } 2018 \\
\text { Available Online: } \\
\text { 10 March } 2018\end{array}$ \\
\hline
\end{tabular}

\section{Introduction}

Wheat (Triticum aestivum L.) is the second most important staple food crop of the world accounting nearly $30 \%$ of global cereal production covering an area of 218.5 million hectare with an average productivity of 3.26 tonnes $\mathrm{ha}^{-1}$ (FAO, 2014). Its area and productivity is increasing rapidly adopting across the globe, due to its wider adaptability sustainability under divers agro climatic
Field experiment was conducted during Rabi season of 2010-11 and 2011-12 at Research farm of CCS Haryana Agricultural University, Hisar, India to study agrometeorological indices on phenology and yield of wheat cultivars as influenced by Late, very late sown heat stress condition. The experiment was laid out in split plot design with two sowing time viz., late $\left(16^{\text {th }}\right.$ Dec. $)$ and very late $\left(5^{\text {th }} \mathrm{Jan}\right.$.) in main plot and four late sown genotypes (PBW 373, WH 1021, PBW 590 and PBW 550) in sub plots with three replications. On the basis of two years pooled data it was revealed that $16^{\text {th }}$ Dec. sown wheat took maximum calendar days (129 days), GDD (1546 ${ }^{\circ} \mathrm{C}$ day), HTU (11421 ${ }^{\circ}$ days hour) and PTU (18143 ${ }^{0}$ days hour) for all the phenophases upto maturity, which got reduced significantly with very late sowing of wheat on $5^{\text {th }}$ Jan., grain yield and biological yield recorded with $16^{\text {th }}$ Dec. sown crop were significantly higher by 14.8 and 13.2 percent over very late sowing of $5^{\text {th }}$ Jan. Among the varieties, PBW 550 was recorded with maximum effective tillers $/ \mathrm{m}^{2}$ (419), highest grain (44.5 q/ha), biological yield (114 q/ha), GY HUE $\left(3.02 \mathrm{~kg} \mathrm{ha}^{-1}\right.$ day $\left.^{-1}\right)$ and BY HUE (7.74 kg ha $\left.{ }^{-1} \mathrm{day}^{-1}\right)$. PBW 373 recorded maximum GDD $\left(926\right.$ and $1540^{\circ} \mathrm{C}$ day), HTU (6416 and $11689^{\circ}$ days hour), PTU (10554 and $18222^{\circ}$ days hour) and PTI (10.2 and $12.7^{\circ} \mathrm{C}$ days day $\left.{ }^{-1}\right)$ upto heading and maturity. Due to very late sowing ( $5^{\text {th }} \mathrm{Jan}$.), maximum reduction in grain yield of about 17.1 percent was recorded in PBW 550, followed by PBW 373 (14.7\%) and PBW 590 (14.7\%) and minimum reduction in WH $1021(12.5 \%)$ as compared to $16^{\text {th }}$ Dec. sown crop. 
crucial factors deciding its productivity. Late sown wheat faces low temperature in the earlier and high temperature stress in the later part of the growing season and requires favourable moisture for better growth and development in late March and early April. Late sown wheat resulted as exposure to high temperature influencing macro and microsporogenesis process during reproductive development which ultimately causes reduction in grain yields. Normal sowing crop requires higher GDD requirement than the later growing one. Late sowing decreased the duration of phenology as compared to normal sowing due to fluctuated un-favourable high temperature during the growth period Ram et al., (2012), Gill et al., (2016). In particular, higher temperatures during vegetative stage significantly reduced the magnitude of sink components like culm length, spike length, duration from heading to maturation, and thousand-grain weights showing a significant inverse correlation to mean seasonal ambient temperatures. This also shortens the duration from heading to maturation resulting in smaller grain size and decline in thousandgrain weight (Nishio et al., 2013 and Singh and Dwivedi, 2015). Delay in sowing of wheat beyond 15 Dec., resulted in yield reduction of $50 \mathrm{~kg}$ grain/day/ha (Singh et al., 2001). Studies conducted in NW India showed that sowing with delays from a timely period (first fortnight of Nov.) to a late period (first fortnight of Dec.) resulted in reductions of grain yield @ $32.0 \mathrm{~kg} \mathrm{ha}^{-1} \mathrm{day}^{-1}$ (Tripathi et al., 2005, Kumar et al., 2008; Ram et al., 2012) noticed that delay in sowing beyond normal sowing reduces grain yield by 16.2 , 37.4 and 59.9 percent under moderately late ( 7 Dec.), late (21 Dec.) and very late (7 Jan.) sown conditions, respectively. Patra and Sahu, (2007) attempted to identify suitable sowing dates of wheat through agrometeorological indices. Number of new genotypes of wheat are playing an important role in the human nutrition and solving food problem, but as a result of heat stress, the performance of these genotypes is often hampered, so it is necessary to develop heat tolerant genotypes. A better insight in the magnitude of genotype and temperature interaction on stability of growth and yield attributes, and quality characteristics under heat stress is required so as to select quality traits under increasing weather extremes as a consequence of future climate change (Spiertz, 2006). Adopting suitable sowing date and appropriate cultivar choices were estimated to be avoiding 7-18\% of global yield losses due to changed scenarios of temperature and precipitation in 2050s (Deryng et al., 2011).

Light response not only controls the temperature factor but also regulates the vegetative growth as well as flowering of the plants, is important weather element for wheat crop to assess the thermal response and its requirement during different phenophases to harvest potential yield. Temperature based indices such as GDD, HTU, PTU, PTI can be relatively useful for predicting growth and yield of crop. The concept of GDD are based on the concept that real time to attain a phonological stage is linearly related to prevailed temperature in range between base temperature and optimum temperature (Singh and Khushu, 2012). The quantification of HUE is useful for the assessment of yield potential of a crop in different environment. Performance of newly evolved cultivars was evaluated under late and very late sowing condition to identify the best-suited cultivar for late sowing in Hisar conditions.

\section{Materials and Methods}

The field experiment was conducted at Research Farm of CCS Haryana Agricultural University, Hisar, India (29 $10^{\circ} \mathrm{N}$ latitude, $75^{\circ} 46^{\prime} \mathrm{E}$ longitude and 215.2 $\mathrm{M}$ altitude) during Rabi season of 2010-11 and 2011-12. The soil of the field was sandy loam in 
texture, slightly alkaline in $\mathrm{pH}$ (7.9), low in organic carbon, poor in available nitrogen and medium in available phosphorus and available potassium. The experiment was laid out in split plot design with two sowing dates $\left(16^{\text {th }}\right.$ Dec. and $5^{\text {th }}$ Jan.) in main plot and four genotypes (PBW 373, WH 1021, PBW 590 and PBW 550) in sub plots with three replications. The crop was sown manually with hand plough on $16^{\text {th }}$ Dec. and $5^{\text {th }} \mathrm{Jan}$. in both the years of study using the seed rate of $100 \mathrm{~kg} / \mathrm{ha}$ at a row to row spacing of $20 \mathrm{~cm}$. Full dose of $\mathrm{P}_{2} \mathrm{O}_{5}(62.5 \mathrm{~kg} / \mathrm{ha})$ and $1 / 3^{\text {rd }}$ dose of nitrogen $(50 \mathrm{~kg} / \mathrm{ha})$ was applied basal at the time of sowing. The remaining $2 / 3^{\text {rd }}$ dose of nitrogen were applied in 2 equal doses, half at CRI stage and the rest half at tillering stage. To control weeds one hand weeding was done at 30 DAS in all the treatments. Other management practices were adopted as per recommendations of the wheat crop under irrigated late sown condition. Data on plant height, number of effective tillers, number of grains/earhead, 1000 grain weight, grain yield and biological yield were recorded by using standard procedure.

During 2010-11, $16^{\text {th }}$ Dec. and $5^{\text {th }}$ Jan. sown crop were harvested on $24^{\text {th }}$ and $30^{\text {th }}$ April, respectively, while in $2011-12,16^{\text {th }}$ Dec. and $5^{\text {th }}$ Jan. sown crop were harvested on $1^{\text {st }}$ and $5^{\text {th }}$ May, respectively. During crop season the meteorological data, viz., rainfall, relative humidity, maximum $\left(\mathrm{T}_{\max }\right)$ and minimum temperature $\left(\mathrm{T}_{\min }\right)$, bright sunshine hours (BSS) and pan evaporation etc. were recorded from Agrometeorological observatory, CCS HAU, Hisar (Fig. 1). The agro-meteorological indices were computed using the daily meteorological data. The dates of occurrences of different phenological events, viz. heading and physiological maturity were recorded when 75 per cent of the plants in each replication reached the respective stages. The analysis was done using OPSTAT programme available online on CCS Agricultural
University, HISAR web site. The different temperature based meteorological indices such as growing degree days (GDD), helio-thermal unit (HTU), photo-thermal unit (PTU), phenothermal index (PTI) and heat use efficiency (HUE) were calculated using the standard formulae (Gill et al., 2014).

\section{Results and Discussion}

\section{Weather prevailed during 2010-11 and 2011-12}

Weekly $\mathrm{T}_{\max }$ and $\mathrm{T}_{\min }$ ranges were 11.2$33.2^{\circ} \mathrm{C}$ and $3.1-15.5^{\circ} \mathrm{C}$ during $2010-11$ and weekly $\mathrm{T}_{\max }$ and $\mathrm{T}_{\min }$ ranges were $17.0-35.6^{\circ} \mathrm{C}$ and $1.2-19.0^{\circ} \mathrm{C}$, respectively during $2011-12$ (Fig. 1). During crop season highest $\left(33.2{ }^{\circ} \mathrm{C}\right)$ and lowest $\left(11.2{ }^{\circ} \mathrm{C}\right)$ weekly mean $\mathrm{T}_{\max }$ was recorded in $13^{\text {th }} \& 1^{\text {st }}$ SMWs, respectively in 2010-11 and highest $\left(35.6{ }^{\circ} \mathrm{C}\right)$ and lowest (17 ${ }^{\circ} \mathrm{C}$ ) weekly mean $\mathrm{T}_{\max }$ was recorded in $14^{\text {th }}$ and $2^{\text {nd }}$ SMWs in 2011-12. Whereas, weekly mean $\mathrm{T}_{\min }$, the highest $\left(15.5^{\circ} \mathrm{C}\right)$ and lowest $\left(3.1^{\circ} \mathrm{C}\right)$ were recorded during $46^{\text {th }} \& 50^{\text {th }}$ SMWs, respectively during 2010-11 and during 2011-12, the highest $\mathrm{T}_{\min }\left(19.0^{\circ} \mathrm{C}\right)$ and lowest $\left(1.2^{\circ} \mathrm{C}\right)$ were recorded during $14^{\text {th }}$ and $52^{\text {nd }}$ SMWs, respectively. During the crop season of 2010-11, the rainfall of 43.6, 24.2, $8.2,6.7,3.6,4.6$ and $10.3 \mathrm{~mm}$ was received in $52^{\text {nd }}, 7^{\text {th }}, 8^{\text {th }}, 9^{\text {th }}, 10^{\text {th }}$ and $14^{\text {th }}$ SMWs. Only the rainfall of $14.4 \mathrm{~mm}$ was received during the $3^{\text {rd }}$ standard week of 2011-12 crop seasons. The brightest week during the crop season of 2010-11 was $11^{\text {th }}$ week with 9.5 hrs per day, whereas, $1^{\text {st }}$ week was the least bright with 1.2 hrs per day. During 2011-12, $9^{\text {th }}$ week was brightest week with 9.0 hrs per day, whereas, $1^{\text {st }}$ week was the least bright with $1.8 \mathrm{hrs}$ per day. Evaporative demand was highest in $14^{\text {th }}$ standard week with $4.5 \mathrm{~mm}$ per day, whereas the lowest open pan evaporation was recorded in $2^{\text {nd }}$ standard week with $0.7 \mathrm{~mm}$ per day, respectively during 2010-11 and during 201112, the highest evaporative demand was 
recorded in $14^{\text {th }}$ standard week with $5.9 \mathrm{~mm}$ per day, whereas the lowest open pan evaporation was recorded in $1^{\text {st }}$ standard week with $0.8 \mathrm{~mm}$ per day.

\section{Plant Growth}

\section{Plant height (cm)}

Significant differences were exhibited with date of sowing and cultivars on plant height (Table 1). A significant reduction in plant height was recorded with delayed sowing during both the years. The reduction in plant height was $10.23,6.34$ and 8.30 percent during 2010-11, 2011-12 and in pooled mean, respectively. Decrease in plant height in very late sown conditions was due to shorter growing period (Table 4).

These results are similar by Kumar et al., (2013) reported reduction in plant height with delayed sowing. Wheat genotypes showed significant differences for plant height. Tallest plants were recorded with WH 1021 (101 and $105 \mathrm{~cm}$ during 2010-11 and 2011-12, respectively) which were significantly superior to all other genotypes but shortest plants was recorded with PBW550 during both the years. Differences in plant height among varieties might be attributed to their genetic diversity.

\section{Yield attributes}

\section{Effective tillers $/ \mathbf{m}^{2}$}

Delayed sowing decreased the effective tillers $/ \mathrm{m}^{2}$ significantly during both the years (Table 1). Reduction in effective tillers $/ \mathrm{m}^{2}$ due to delayed sowing was more during 2010-11 $(13.36 \%)$ as compared to 2011-12 (7.71\%). On mean basis, the reduction in effective tillers $/ \mathrm{m}^{2}$ was 10.52 percent due to delayed sowing. Singh and Dwivedi (2015) also found reduction in effective tillers $/ \mathrm{m}^{2}$ with delay in sowing. This might be due to favourable temperature requirement as per crop need boosting crop growth in the form of higher photosynthate accumulation and resulting higher yield parameters in normal sown crop than late sown (Mukerjee, 2012; Kumar et al., 2013; Elrahman et al., 2014). Among genotypes, the maximum tiller (380.5) was recorded with PBW 373 in first year, however, in the second year PBW 550 produced higher numbers of effective tillers (459). On pooled mean basis, maximum tillers $/ \mathrm{m}^{2}$ was recorded in PBW 550, which was 1.82, 4.49 and 11.15 percent higher than WH 1021, PBW 373 and PBW 590, respectively. Differences in tillers among genotypes might be due attributed to their genetic diversity (Mumtaj et al., 2015).

\section{Grains/earhead}

Pooled means of two years indicate that numbers of grains/spike were not affected by time of sowing. Wheat cultivars also did not affect number of grains per spike significantly. Similar findings have also been observed by Yajam and Madani (2013), who reported that number of grains/spike was not affected by different varieties.

\section{0 grain weight}

Data revealed that 1000 grain weight decreased significantly by delayed sowing during both the years. The bolder grain was recorded in $16^{\text {th }}$ Dec. sowing as compared to $5^{\text {th }}$ Jan. sowing. The reduction in grain weight was $8.54,6.14$ and 7.27 percent during 2010$11,2011-12$ and on pooled mean basis, respectively. The reduction in test weight in delay sowing was mainly due to less production of photosynthate due to shorter growth period and shriveling of grain due to winds prevailed during milk and grain filling stage. These results are in line with those of Kumar et al., (2013); Eslami et al., (2014); Singh and Dwivedi (2015). Among the 
varieties, the maximum 1000 grain weight (36.45) was recorded with PBW 373, which was significantly higher than WH 1021 and PBW 590 but at par with 550. The grain weight in genotype PBW 373 was $0.88,4.25$ and 5.35 percent higher than PBW 550, WH 1021 and PBW 590, respectively. Differences in 1000-grains weight of wheat cultivars seem to be due to their genotypic variations (Mahmood et al., 2014). This higher 1000 grain weight of PBW 373 can justified owing to favourable temperature requirement as per crop need boosting crop growth in the form of higher photosynthate accumulation and resulting higher 1000 grain weight. Similar finding have been observed by Kumar et al., (2013).

\section{Days taken to phenophases}

Sowing times and varieties had significantly affected the days taken to different phenophases viz. Heading and maturity (Table 4). The crop sown on Dec. 16 took significantly higher number of day's upto heading (97) and maturity (129), which were 13.4 and 13.9 percent, respectively higher than very late sowing on $5^{\text {th }}$ Jan. The very late sown crop completed its life cycle at an accelerated pace, leading to shortening of days taken for the development of its different phenophases up to maturity. In late planted wheat, time to heading shortens in a curvilinear fashion as temperature increases and grain development period is reduced and crop matures early (Khokhar et al., 2010; Suleiman et al., 2014 and Mumtaj et al., 2015).Among varieties PBW 373 and PBW 550 took the maximum and minimum days, respectively for all the phenophases upto maturity. Elrahman et al., (2014) reported the significant differences among the genotypes with respect to the number of days to phenophases indicate that each of these genotypes has its own genetic characteristics with respect to this trait.
Grain and biological yield and harvest index

The yield difference between 2010-11 and 2011-12 might be attributed to variable temperature, leading to better leaf area duration, average crop growth rate and long grain filling period during 2nd year of experimentation, which is similar to the finding of Sokoto and Singh (2013) observed that the duration of grain filling in cereals (wheat) is determined by temperature.

Pooled data of two experimental years revealed that the crop sown on Dec. 16 recorded the highest grain yield (46.2 q/ha) and biological yield (119.2 q/ha) which were significantly higher by 14.8 and 13.2 percent, respectively than very late planting on $5^{\text {th }}$ Jan. (Table 2). It might be due to higher yield attributes, GDD, HTU and PTU in this sowing date (Table 4). The detrimental effect of heat at later stage of crop development and earhead emergence in very late sowing was adverse effect on grain yield. In late planted wheat, time to heading shortens in a curvilinear fashion as temperature increases and grain development period is reduced and crop matures early. Harvest index was affected non-significantly by sowing times.

Among late sown varieties PBW 550 recorded the highest grain yield (44.5 q/ha) which was significantly higher than PBW 373 (42.4 q/ha) and PBW 590 (41.0 q/ha) but at par with WH 1021 (43.0 q/ha). Highest grain yield in PBW 550 could be attributed to its maximum number of effective tillers $/ \mathrm{m}^{2}$ (419) observed and yield variation among varieties might be due difference in their genetic potential. The maximum biological yield (114.0 q/ha) was found with PBW 550, which was significantly higher than PBW 590 but statistically at par with PBW 373 and WH 1021. It might be due to maximum number of effective tillers in PBW 550. 
Table.1 Effect of date of sowing and varieties on plant height and yield attributes of wheat

\begin{tabular}{|c|c|c|c|c|c|c|c|c|c|c|c|c|}
\hline \multirow[t]{2}{*}{ Treatments } & \multicolumn{3}{|c|}{ Plant height (cm) } & \multicolumn{3}{|c|}{ Effective tillers $/ \mathrm{m}^{2}$} & \multicolumn{3}{|c|}{ Grains/earhead } & \multicolumn{3}{|c|}{ 1000-grains weight } \\
\hline & 2010-11 & 2011-12 & pooled & 2010-11 & 2011-12 & pooled & 2010-11 & 2011-12 & pooled & 2010-11 & 2011-12 & pooled \\
\hline \multicolumn{13}{|c|}{ Date of Sowing } \\
\hline Late & 97.00 & 95.83 & 96.42 & 401.42 & 446.17 & 424.1 & 30.09 & 29.20 & 29.64 & 35.60 & 38.11 & 36.85 \\
\hline Very Late & 87.08 & 89.75 & 88.42 & 346.50 & 411.75 & 379.5 & 31.94 & 29.27 & 30.60 & 32.56 & 35.77 & 34.17 \\
\hline $\mathrm{SE}(\mathrm{m})$ & 0.77 & 0.60 & 0.14 & 6.85 & 2.83 & 4.79 & 0.29 & 1.23 & 0.71 & 0.06 & 0.24 & 0.14 \\
\hline LSD & 4.77 & 3.69 & 0.83 & 45.25 & 17.48 & 29.58 & 1.79 & NS & NS & 0.38 & 1.45 & 0.84 \\
\hline \multicolumn{13}{|l|}{ Genotypes } \\
\hline PBW 373 & 94.00 & 93.83 & 93.92 & 380.50 & 420.33 & 400.67 & 30.88 & 27.61 & 29.24 & 35.23 & 37.66 & 36.45 \\
\hline WH 1021 & 101.00 & 105.00 & 103.00 & 380.17 & 441.33 & 411.17 & 29.23 & 31.00 & 30.12 & 35.25 & 34.54 & 34.90 \\
\hline PBW 590 & 86.67 & 87.17 & 86.92 & 357.67 & 395.17 & 376.67 & 32.48 & 30.58 & 31.53 & 31.39 & 37.75 & 34.57 \\
\hline PBW 550 & 86.50 & 85.17 & 85.83 & 377.50 & 459.00 & 418.67 & 31.48 & 27.73 & 29.61 & 34.44 & 37.81 & 36.13 \\
\hline SE (m) & 0.82 & 0.63 & 0.41 & 4.45 & 10.92 & 4.79 & 0.69 & 1.15 & 0.71 & 0.27 & 0.62 & 0.36 \\
\hline LSD & 2.52 & 1.93 & 1.26 & 13.72 & 33.63 & 29.58 & 2.12 & NS & NS & 0.83 & 1.90 & 1.12 \\
\hline
\end{tabular}

Table.2 Effect of date of sowing and varieties on yield and harvest index of wheat

\begin{tabular}{|c|c|c|c|c|c|c|c|c|c|c|c|c|}
\hline \multirow[t]{2}{*}{ Treatments } & \multicolumn{3}{|c|}{ Grain yield (q/ha) } & \multicolumn{3}{|c|}{ Straw yield (q/ha) } & \multicolumn{3}{|c|}{ Biological yield (q/ha) } & \multicolumn{3}{|c|}{ Harvest index (\%) } \\
\hline & 2010-11 & 2011-12 & pooled & 2010-11 & 2011-12 & pooled & 2010-11 & 2011-12 & pooled & 2010-11 & 2011-12 & pooled \\
\hline \multicolumn{13}{|l|}{$\begin{array}{l}\text { Date of } \\
\text { Sowing }\end{array}$} \\
\hline Late & 42.94 & 49.35 & 46.15 & 79.93 & 66.14 & 73.03 & 122.87 & 115.49 & 119.19 & 34.93 & 42.72 & 38.82 \\
\hline Very Late & 35.97 & 42.69 & 39.33 & 63.63 & 64.66 & 64.14 & 99.60 & 107.35 & 103.47 & 36.13 & 39.77 & 37.95 \\
\hline SE (m) & 0.56 & 1.03 & 0.31 & 1.03 & 1.65 & 0.94 & 1.32 & 2.66 & 1.25 & 0.37 & 0.15 & 0.20 \\
\hline LSD & 3.48 & 6.36 & 1.93 & 6.33 & NS & 5.83 & 8.17 & NS & 7.73 & NS & 0.94 & NS \\
\hline \multicolumn{13}{|l|}{ Genotypes } \\
\hline PB W 373 & 41.34 & 43.53 & 42.44 & 74.31 & 63.76 & 69.03 & 115.65 & 107.29 & 111.47 & 35.70 & 40.58 & 38.14 \\
\hline WH 1021 & 39.05 & 46.99 & 43.02 & 70.25 & 66.92 & 68.59 & 109.30 & 113.91 & 111.61 & 35.92 & 41.18 & 38.55 \\
\hline PBW 590 & 36.49 & 45.50 & 40.99 & 70.24 & 64.25 & 67.25 & 106.72 & 109.75 & 108.24 & 34.40 & 41.41 & 37.91 \\
\hline PBW 550 & 40.95 & 48.05 & 44.50 & 72.31 & 66.68 & 69.49 & 113.26 & 114.73 & 114.00 & 36.09 & 41.80 & 38.95 \\
\hline SE (m) & 0.94 & 0.83 & 0.56 & 0.89 & 1.24 & 0.68 & 1.51 & 2.01 & 1.08 & 0.49 & 0.22 & 0.28 \\
\hline LSD & 2.91 & 2.55 & 1.71 & 2.74 & NS & NS & 4.64 & NS & 3.32 & NS & 0.66 & NS \\
\hline
\end{tabular}


Table.3 Interaction effect of date of sowing on grain yield (q/ha) of different wheat genotypes during 2010-11, 2011-12 and on pooled

\begin{tabular}{|c|c|c|c|c|c|c|c|c|c|}
\hline \multirow[t]{2}{*}{ Genotypes } & \multicolumn{2}{|c|}{$2010-11$} & \multirow[t]{2}{*}{ Mean } & \multicolumn{2}{|c|}{$2011-12$} & \multirow[t]{2}{*}{ Mean } & \multicolumn{2}{|c|}{ Pooled mean } & \multirow[t]{2}{*}{ Mean } \\
\hline & $16^{\text {th }}$ Dec. sowing & $5^{\text {th }}$ Jan. sowing & & $16^{\text {th }}$ Dec. sowing & $5^{\text {th }}$ Jan. sowing & & $16^{\text {th }}$ Dec. sowing & $5^{\text {th }}$ Jan. sowing & \\
\hline PBW 373 & 46.02 & 36.66 & 41.34 & 45.61 & 41.45 & 43.53 & 45.82 & 39.06 & 42.44 \\
\hline WH 1021 & 40.92 & 37.17 & 39.05 & 50.84 & 43.15 & 46.99 & 45.88 & 40.16 & 43.02 \\
\hline PBW 590 & 39.66 & 33.13 & 36.49 & 48.82 & 42.18 & 45.50 & 44.24 & 37.75 & 41.00 \\
\hline PBW 550 & 45.17 & 36.73 & 40.95 & 52.14 & 43.96 & 48.05 & 48.65 & 40.35 & 44.50 \\
\hline Mean & 42.94 & 35.97 & & 49.35 & 42.69 & & 46.15 & 39.33 & \\
\hline \multicolumn{10}{|l|}{ C.D. } \\
\hline Sowing date (A) & & 3.48 & & & 6.36 & & & 1.93 & \\
\hline Variety $(B)$ & & 2.91 & & & 2.55 & & & 1.71 & \\
\hline B within A & & NS & & & NS & & & NS & \\
\hline A within B & & NS & & & NS & & & NS & \\
\hline
\end{tabular}

Table.4 Effect of date of sowing and varieties on accumulated agrometeorological indices and HUE on grain and biological of wheat (pooled)

\begin{tabular}{|c|c|c|c|c|c|c|c|c|c|c|c|c|c|c|c|c|}
\hline \multirow[t]{2}{*}{ Treatments } & \multicolumn{2}{|c|}{ Phenology } & \multicolumn{2}{|c|}{ GDD $\left({ }^{\circ} \mathrm{C}\right.$ day $)$} & \multicolumn{2}{|c|}{ HTU $\left({ }^{\circ}\right.$ C day $)$} & \multicolumn{2}{|c|}{ PTU $\left({ }^{\circ} \mathbf{C}\right.$ day $)$} & \multicolumn{2}{|c|}{$\operatorname{Tp}\left({ }^{\circ} \mathbf{C}\right)$} & \multicolumn{2}{|c|}{$\operatorname{Tn}\left({ }^{\circ} \mathbf{C}\right)$} & \multicolumn{2}{|c|}{ PTI } & \multirow{2}{*}{$\begin{array}{c}\text { GY } \\
\text { HUE(kg } \\
\text { ha }^{-10} \mathrm{C}- \\
\left.\text { 1day }^{-1}\right)\end{array}$} & \multirow{2}{*}{$\begin{array}{c}\text { BY } \\
\text { HUE } \\
\left(\mathrm{kg} \mathrm{ha}^{-1}\right. \\
{ }^{0} \mathrm{C}- \\
\left.\text { 1day }^{-1}\right)\end{array}$} \\
\hline & Heading & Maturity & Heading & Maturity & Heading & Maturity & Heading & Maturity & Heading & Maturity & Heading & Maturity & Heading & Maturity & & \\
\hline $\begin{array}{l}\text { Date of } \\
\text { Sowing } \\
\end{array}$ & & & & & & & & & & & & & & & & \\
\hline Late & 97.08 & 128.5 & 916.1 & 1546 & 6062 & 11421 & 10333 & 18143 & 1738 & 2644 & 991 & 1285 & 9.43 & 12.03 & 2.99 & 7.71 \\
\hline Very Late & 83.50 & 111.0 & 888.5 & 1457 & 6394 & 11255 & 10210 & 17309 & 1602 & 2410 & 946 & 1200 & 10.64 & 13.11 & 2.70 & 7.10 \\
\hline $\mathrm{SE}(\mathrm{m})$ & 0.08 & 0.18 & 0.99 & 3.17 & 11.00 & 32.16 & 11.40 & 40.93 & 1.81 & 4.81 & 0.92 & 4.54 & 0.01 & 0.01 & 0.02 & 0.07 \\
\hline LSD & 0.48 & 1.11 & 6.12 & 19.55 & 67.90 & N.S. & 70.35 & 252.6 & 11.19 & 29.70 & 5.71 & 28.03 & 0.03 & 0.07 & 0.10 & 0.43 \\
\hline Genotypes & & & & & & & & & & & & & & & & \\
\hline PBW 373 & 91.50 & 121.6 & 925.6 & 1540 & 6416 & 11689 & 10554 & 18222 & 1704 & 2582 & 992 & 1272 & 10.16 & 12.70 & 2.75 & 7.24 \\
\hline WH 1021 & 90.25 & 120.3 & 902.3 & 1513 & 6231 & 11445 & 10271 & 17868 & 1670 & 2543 & 969 & 1250 & 10.04 & 12.61 & 2.84 & 7.37 \\
\hline PBW 590 & 89.67 & 118.8 & 890.0 & 1480 & 6131 & 11148 & 10123 & 17458 & 1653 & 2498 & 957 & 1230 & 9.97 & 12.50 & 2.77 & 7.30 \\
\hline PBW 550 & 89.75 & 118.3 & 891.3 & 1472 & 6134 & 11081 & 10137 & 17356 & 1655 & 2486 & 958 & 1219 & 9.98 & 12.47 & 3.02 & 7.74 \\
\hline SE (m) & 0.39 & 0.46 & 7.61 & 9.61 & 63.28 & 92.64 & 92.54 & 122.7 & 11.17 & 13.71 & 7.65 & 8.40 & 0.04 & 0.03 & 0.05 & 0.11 \\
\hline LSD & 1.20 & 1.42 & 23.45 & 29.62 & 194.9 & 285.4 & 285.1 & 378.1 & 34.41 & 42.26 & 23.58 & 25.87 & 0.13 & 0.10 & 0.15 & 0.33 \\
\hline
\end{tabular}


Fig.1 Weather conditions prevailed during 2010-11 and 2011-12

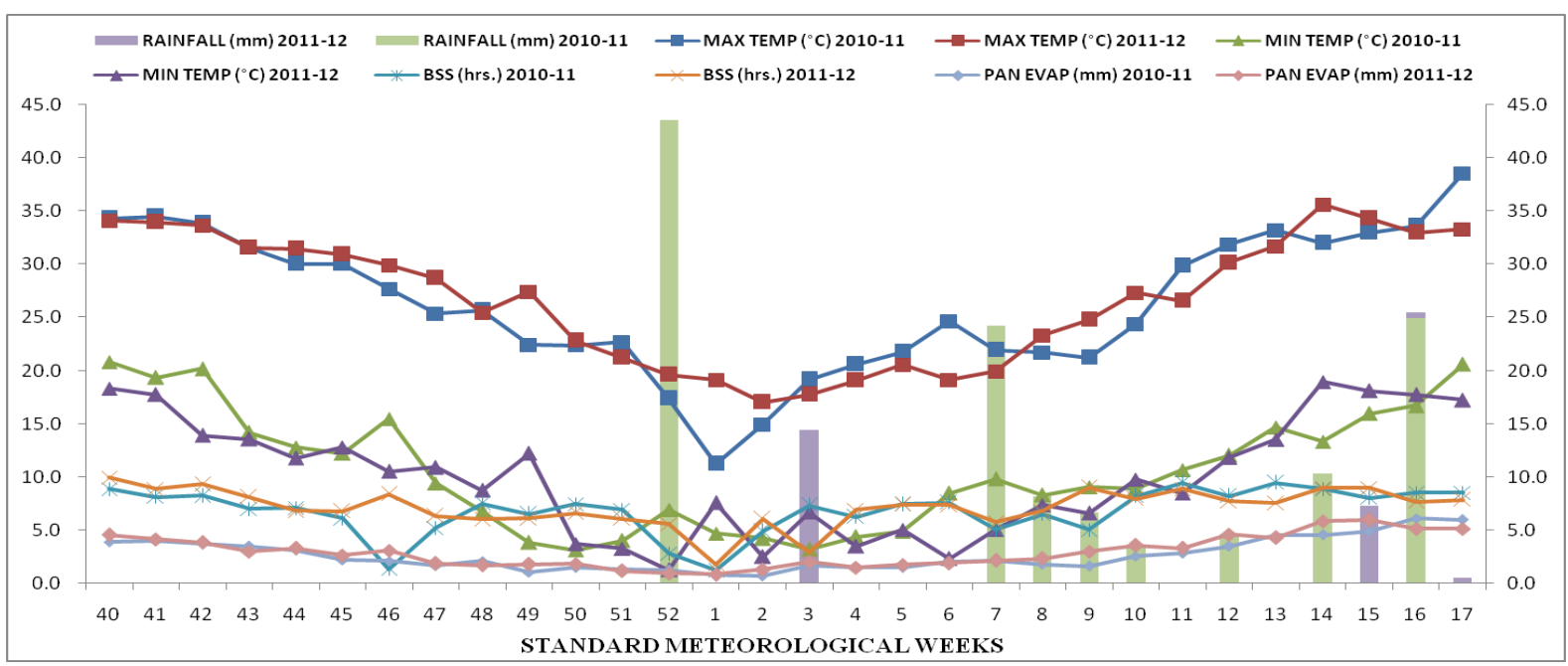

Varietal change had significantly affected the harvest index. PBW 373 was found with highest harvest index $(36.45 \%)$, which was significantly higher than all varieties except PBW 550.

The interaction effect between dates of sowing and wheat varieties was found to be non-significant (Table 3). On pooled mean study of two years resulted that all the late sown varieties produced significantly higher grain yield in $16^{\text {th }}$ Dec. sowing as compared to very late $5^{\text {th }}$ Jan. The greater reduction in yield of wheat varieties under delayed sowing situations was attributed to decrease in season length, which might have reduced their yield. Delayed sowing hastened the crop phenological development, thereby causing significant reduction in wheat yields and yield. Das and Mitra (2013); Jat et al., (2013); Elrahman et al., (2014); Suleiman et al., (2014); Munsif et al., (2015) also reported the similar observation under delayed sowing. Higher grain yield in timely planting wheat was also recorded by Ram et al., (2012) due to increased higher growing degree days, photo-thermal units and yield attributes. Due to very late sowing on $5^{\text {th }} \mathrm{Jan}$. the maximum reduction in grain yield of about 17.1 percent was recorded in PBW 550, followed by PBW
373 (14.7\%) and PBW $590(14.7 \%)$ and minimum reduction in $\mathrm{WH} 1021(12.5 \%)$ as compared to $16^{\text {th }}$ Dec. sown crop. However, on mean basis 14.8 percent reduction in grain yield of wheat was recorded in very late sowing $5^{\text {th }}$ Jan. sowing as compared to $16^{\text {th }}$ Dec. sown crop. The relatively better performance of the genotypes in the optimum sowing than in late sowing may result from the better development of the grains due to longer growing period as wheat had more time for the dry matter accumulation to produce the higher grain yield (Elrahman et al., 2014)

\section{Growing degree days (GDD)}

Accumulated growing degree days upto different phenophasis were recorded with significant difference under different sowing times and varieties (Table 4). $16^{\text {th }}$ Dec. sown wheat was found with 3.05 and 5.76 percent significantly higher GDD up to heading and maturity, respectively over $5^{\text {th }}$ Jan. sown crop. Pandey et al., (2010) also reported lower consumption of heat units under delayed sowing. The requirement of GDD was higher for late sown condition than the very late growing condition. This was due to longer period for all the phenological stages in the 
late sown than very late sown conditions. Very late sowing decreased the duration of phenology as compared to late sowing due to fluctuated unfavourable high temperature during the growing period. So, the requirement of heat units decreased for different phenological stages with late sowing. Similar results were also reported by Kumar and Kumar (2014). The GDD upto heading were acquired maximum (925.6) and minimum (890.0) by PBW 373 and PBW 590, respectively. For maturity the maximum GDD was reported with PBW 373 (1570) which was statistically at par with WH 1021. Early development of phonological stages might be the reason for less consumption of heat units in late sown wheat varieties viz., PBW 590 and PBW 550. The less number of days taken by PBW 550 and PBW 590 for development of various phenophases could be a reason for its significantly minimum GDD values.

\section{Helio-thermal unit (HTU)}

The $16^{\text {th }}$ Dec. sown wheat consumed higher HTU at maturity as compared to $5^{\text {th }}$ Jan. crop, but statistically at par (Table 4). This might be due to 17 more days taken to maturity in late sown as compared to very late sown crop. Dec. HTU for different phenological stages due to delayed sowing were also reported by Bishnoi et al., 1995; Paul and Sarker 2000; Haidar et al., 2003 in wheat, Alam et al., 2007 in barley and Akhtar et al., 2015 in rapeseed. Among different varieties maximum accumulated HTU at heading and maturity was found with PBW373 (6416 and $11689^{0}$ day hour), which was statistically at par with WH 1021 and significantly higher than PBW 550 and PBW 590.

\section{Photo-thermal unit (PTU)}

The data presented in Table 4 revealed that $26^{\text {th }}$ Dec. sown crop used significantly higher PTU by 1.19 and 4.60 percent, respectively for heading and maturity over very late sown crop on $5^{\text {th }}$ Jan. Among genotypes, PBW was observed with significantly highest PTU consumed for different phenophases, while lower PTU used for heading and maturity were found with PBW 550 (10137 and 17356) and PBW 590 (10123 and 17458), respectively, were significantly lower than PBW 373 (10554 and 18222) at heading and maturity. The higher PTU value in early sown crop may be due to fact that crop took longer duration to reach phenological stages (Amrawat et al., 2013).

\section{Pheno-thermal index (PTI)}

Pheno-thermal index was more at maturity than at heading (Table 4). Upto heading and maturity 11.4 and 8.24 percent significantly higher PTI value respectively were observed in $5^{\text {th }}$ Jan. sown crop over the $16^{\text {th }}$ Dec. sown wheat. Among different varieties, maximum PTI values of 10.2 and 12.7 during heading and maturity, respectively were found with PBW 373 and these were statistically at par WH 1021 but significantly higher than PBW 550 and PBW 590. It might be due to variation in number of days taken during different phenophases. From the overall results it was found that the heat tolerant cultivar PBW 373 had the highest PTI at heading to maturity stage of late growing condition. Similar findings have been observed by Sikder et al., (2009).

\section{Grain and biological heat use efficiency (GY HUE and BY HUE)}

Crop sown on $16^{\text {th }}$ Dec. showed significantly higher HUE of $2.99 \mathrm{~kg} \mathrm{ha}^{-1} \mathrm{day}^{-1}$ and $7.71 \mathrm{~kg}$ $\mathrm{ha}^{-1}$ day $^{-1}$ grain and biological yield, respectively (Table 4). The HUE was decreased significantly with delay in sowing. Higher HUE in $16^{\text {th }}$ Dec sown crop could be attributed to higher grain and biological yield. Similar findings were also reported by Sikder 
et al., (2009); Kingra and Kaur (2012); Amrawat et al., (2013); Kumar and Kumar (2014). In contrast, high temperature and water deficiency hampered normal metabolic activities resulted in lower grain yield as well as HUE in sown crop (Haider et al., 2003). Among the varieties PBW 550 was found with maximum grain yield heat use efficiency (3.02 $\mathrm{kg} \mathrm{ha}^{-1}$ day $^{-1}$ ) and biological yield heat use efficiency $\left(7.74 \mathrm{~kg} \mathrm{ha}^{-1}\right.$ day $^{-1)}$, which was significantly higher than all other varieties. The higher value of HUE in PBW 550 might be attributed to their respective higher grain and biological yields. These findings are in confirmation with Singh and Khushu (2012).

\section{Photo temperature (Tp)}

The photo temperature significantly influenced by different sowing dates (Table 4). The photo temperature was significantly higher in the late sown (1738 and $2644{ }^{\circ} \mathrm{C}$ ) than very late sown conditions (1602 and $2406{ }^{\circ} \mathrm{C}$ ) at heading to maturity (Patra et al., (2016). Among the varieties, PBW 373 recorded highest $\mathrm{Tp}\left(2582{ }^{\circ} \mathrm{C}\right)$ and minimum was recorded in PBW $550\left(2486{ }^{\circ} \mathrm{C}\right)$ at maturity. The maximum photo temperature was recorded by PBW 373 might be due to more days taken to heading and maturity as compared to other varieties.

\section{Nycto temperature (Tn)}

The nycto temperature (Tn) significantly influenced by different sowing dates (Table 4). The nycto temperature was higher in the late sown (991 and $1285{ }^{\circ} \mathrm{C}$ ) than very late sown conditions (946 and $1200{ }^{\circ} \mathrm{C}$ ) at heading to maturity. Patra et al., (2016) also recorded that $\mathrm{Tn}$ decreased with delay of sowing of wheat crop. Among the varieties, PBW 373 recorded highest $\mathrm{Tp}\left(1272{ }^{\circ} \mathrm{C}\right)$ and minimum was recorded in PBW $550\left(1219{ }^{0} \mathrm{C}\right)$ at maturity. The maximum Tn was recorded by PBW 373 might be due to more days taken to heading and maturity as compared to other varieties.

Results showed that the late sown $\left(16^{\text {th }}\right.$ Dec. $)$ wheat recorded significantly higher yield attributes, yield and attained more values meteorological indices as compared to very late sowing $\left(5^{\text {th }}\right.$ Jan.). Low grain yield resulted from stress is caused by higher temperatures that prevailed during grain filling in very late sown crop. $16^{\text {th }}$ Dec. sown wheat took maximum calendar days (129 days), GDD (1546 ${ }^{0} \mathrm{C}$ day), HTU (11421 ${ }^{0}$ days hour) and PTU (18143 ${ }^{\circ}$ days hour) upto maturity, which got reduced significantly with subsequent delay in sowing time and recorded lowest value on $5^{\text {th }}$ Jan. sown crop. The grain yield and biological yield recorded with $16^{\text {th }}$ Dec. sown crop were significantly higher by 14.8 and 13.2 percent, respectively over very late sowing of $5^{\text {th }} \mathrm{Jan}$. Among the varieties, PBW550 was recorded with maximum effective tillers $/ \mathrm{m}^{2}$ (419), highest grain (44.5 q/ha), biological yield (114 q/ha), GY HUE (3.02 kg ha ${ }^{-1}$ day $\left.^{-1}\right)$ and BY HUE $(7.74 \mathrm{~kg}$ $\mathrm{ha}^{-1}$ day $\left.^{-1}\right)$. PBW 373 recorded maximum GDD (926 and $1540{ }^{\circ} \mathrm{C}$ day), HTU (6416 and $11689{ }^{\circ}$ days hour), PTU (10554 and 18222 ${ }^{0}$ days hour) and PTI (10.2 and $12.7{ }^{\circ} \mathrm{C}$ day's day $^{-1}$ ) upto heading and maturity. Due to very late sowing on $5^{\text {th }}$ Jan. the maximum reduction in grain yield of about 17.1 percent was recorded in PBW 550, followed by PBW $373(14.7 \%)$ and PBW $590(14.7 \%)$ and minimum reduction in $\mathrm{WH} 1021(12.5 \%)$ as compared to $16^{\text {th }}$ Dec. sown crop.

\section{References}

Akhtar, M.T., Mannan, M.A., Kundu, P.B. and Paul, N.K. (2015). Effects of different sowing dates on the phenology and accumulated heat units in three rapeseed (Brassica campestris L.) varieties. Bangladesh J. Bot. 44(1): 97-101.

Alam, M.Z., Haider, S.A. and Paul, N.K. (2007). Influence of sowing date and nitrogen 
fertilizer on the phenology and accumulated heat units in barley. Plant Environ. Dev. 1(2): 75-81.

Amrawat, T., Solanki, N.S., Sharma, S.K., Jajoria, D.K. and Dotaniya, M.L. (2013). Phenology growth and yield of wheat in relation to agrometeorological indices under different sowing dates. African $J$. Agricul. Res., 8(49): 6366-6374.

Aslani, F. and Mehrvar, M.R. (2012). Response of wheat genotypes as affected by different sowing dates. Asian J. Agric. Sci. 4 (1): 72 -74 .

Bishnoi, O.P., Singh, S. and Niwas, R. (1995). Effect of temperature on phenological development of wheat (Triticum aestivum L.) Indian J. Agric. Sci., 65: 211-214.

Das, S. and Mitra, B. (2013). Performance of wheat genotypes under late and very late sowing in sub-Himalayan plains of West Bengal. Crop Res., 46 (1, 2 \& 3): 32-35.

Deryng, D., Sacks, W.J., Barford, C.C. and Ramankutty, N. (2011). Simulating the effects of climate and agricultural management practices on global crop yield. Glob. Biogeoch. Cycles, 25:1-18.

Elrahman, N.M.A., Ali, A.B., Alhadi, M. and Shuang-En, Y. (2014). Afield Screening of Twelve Wheat Genotypes under Late Sowing Conditions. Amer-Eura. J. Agric. Environ. Sci. 14(10): 978-984.

Eslami, H., Navae1, H., Alazmani, A.R. and Shojaei, A.N. (2014). Effect of sowing dates and seeding density on yield of wheat (Triticumm aestivum L.). Intl. Res. J. Appl. Basic. Sci., 8(7): 836-838.

Gill, K. K., Kaur, N. and Gill, R.I.S. (2016). Evaluation of growth and yield of wheat cultivars using agroclimatic indices under poplar based agroforestry system in Punjab. J. Agrometeorol., 18(1): 124-127.

Gill, K.K., Babuta, R., Kaur, N., Kaur, P. and Sandhu, S.S. (2014). Thermal requirement of wheat crop in different agroclimatic regions of Punjab under climate change scenarios. Mausam, 65(3): 417-424.

Haider, S. A., Alam, M. Z., Alam, M. F. and Paul, N. K. (2003). Influence of different sowing dates on the phenology and accumulated heat units in wheat. J. Biol. Sci., 3(10): 932939.
Haider, S.A., Alam, M.Z., Alam, M.F. and Paul, M.K. 2003. Influence of different sowing dates on the phenology and accumulated heat units in wheat. J. Biolo. Sci., 3(10): 932-939.

Jat, L. K., Singh, S. K., Latare, A. M., Singh, R. S. and Patel, C.B. (2013). Effect of date of sowing and fertilizer on growth and yield of wheat in an inceptisol of varanasi. Indian $J$. Agron., 58(4): 611-614.

Khokhar, Z., Hussain, I., Khokhar, B. And Sohail, M. (2010). Effect of planting date on yield of wheat genotypes in Sindh. Pakistan J. Agric. Res. 23: 3-4.

Kingra, P.K. and Kaur, P. (2012). Effect of dates of sowing on thermal utilisation and heat use efficiency of groundnut cultivars in Central Punjab. J. Agril. Phy., 12(1): 54-62.

Kumar, A., Pandey V., Shekh, A.M. and Kumar, M. (2008). Radiation Use Efficiency and Weather Parameter Influence during Life Cycle of Soybean (Glycine max. [L] Mirrll) Production as Well Accumulation of Dry Matter. Ameri. Eura. J. Agron., 1 (2): 4144.

Kumar, P., Sarangi, A., Singh, D.K. and Parihar, S.S. (2014). Wheat performance as influenced by saline irrigation regimes and cultivars. J. Agri. Search, 1 (2): 66-72.

Kumar, S. and Kumar, B. (2014). Thermal time requirement and heat use efficiency (HUE) in wheat crop in Bihar. J. Agrometeorol., 16(1):137-139.

Kumar, S., Alam, P. and Ali, N. (2013). Response of wheat (Triticum aestivum L. e mend. Fori \& Paol.) varieties to sowing dates. J. Res., 25(1): 56-59.

Mahmood, A., Wahla, A. J., Mahmood, R., Ali, and Nawaz, M (2014). Impact of sowing time on yield parameters of selected wheat cultivars under rice-wheat cropping system of District Sheikhupura, Punjab. Biologia. 60(1): 31-36.

Mumtaj, M.Z., Ahmad, M., Aslam, M., Zamil, M., Zaman, M.F., Nasrullah, H.M., Akhtar, M. and Ali, B. (2015). Evaluation of growth and yield attributes of different wheat genotypes sown under various planting times. J. Bio. Agri. Healthcare, 5(19): 8590. 
Munsif, F., Arif, M., Jan, M.T., Ali, K. And Khan, M.J. (2015). Influence of sowing dates on phenological development and yield of dual purpose wheat cultivars. Pak. J. Bot. 47(1): 83-88.

Nishio, Z., Ito, M., Tabiki, T., Nagasawa, K., Yamauchi, H. and Hirota, T. (2013). Influence of higher growing-season temperatures on yield components of winter wheat (Triticum aestivum L.). crop Sci. 53(2): 621-628.

Pandey, I.B., Pandey, R.K., Dwivedi, D.K. and Singh, R.S. (2010). Phenology, heat unit requirement and yield of wheat (Triticum aestivum) varieties under different cropgrowing environment. Indian J. Agric. Sci., 80:136-140.

Patra, B. K. and Sahu, D.D. (2007). Use of agrometeorological indices for suitable sowing time of wheat under South Saurashtra Agroclimatic Zone of Gujarat. $J$. Agrometeorol. 9(1):74-80.

Patra, S.S., Mehera, B. and Rout, S. (2016). Agrometeorological indices under different hydro priming duration and sowing dates of wheat (Triticum aestivum L.). Life Sci. Leaflets. 72: 192-202.

Paul, N.K. and Sarker, D.K. (2000). Accumulated heat units and phenology relationships in wheat as influenced by sowing dates. Bangladesh J. Bot., 29: 45-54.

Ram, A., Pannu, R. K. and Dasharath Prasad. (2012). Effect of management practices on growth, yield and quality of late sown Wheat. Indian J. Agron., 57(1): 92-95.

Sikder, S. (2009). Accumulated heat unit and phenology of wheat cultivars as influenced by late sowing heat stress condition. $J$. Agric. Rural Dev., 7(1\&2): 57-64.

Singh, P. And Dwivedi, P. (2015). Morphophysiological responses of wheat genotypes under late sown condition. Vegetos. 28 (1): 16-25.

Singh, P. and Dwivedi, P. (2015). Morphophysiological responses of wheat (Triticum aestivum L.) genotypes under late sown condition. Vegetos., 28(1): 16-25.

Singh, S.B., Sarma, B.K and Datta, K.K. (2001). Transition in agriculture of north eastern hill states on India - implication and development. Indian J. Hill Farming, 14(2): 1-12.

Singh,M. and Khushu,,M.K. (2012). Growth and yield prediction of wheat in relation to agroclimatic indices under irrigated and rainfed condition. J. Agrometeorol., 14(1):63-66.

Sokoto, M.B. and Singh, A. (2013). Yield and yield components of bread wheat as influenced by water stress, sowing date and cultivar in Sokoto, Sudan Savannah, Nigeria. Amer. J. Plant Sci., 4: 122-130.

Spiertz, J.H.J., Hamer, R.J., Xu, H., PrimoMartin, C., Don, C. and Putten, P.E.L. (2006). Heat stress in wheat, Effects on grain growth and quality traits. Eur. J. Agron., 25: 89-95.

Suleiman, A.A., Nganya, J.F. and. Ashraf, M.A. (2014). Effect of cultivar and sowing date on growth and yield of wheat (Triticum aestivum L.) in Khartoum, Sudan. J. Forest Products Indus., 3(4): 198-203.

Tripathi, S.C., Mongia, A.D., Sharma, R.K., Kharub, A.S. and Chhokar, R.S. (2005). Wheat productivity at different sowing dates in various agroclimatic zones of India. SAARC J. Agri., 3: 191-201.

Yajam, S. and Madani, H. (2013). Delay sowing date and its effect on Iranian winter wheat cultivars yield and yield components. Annals Biol. Res., 4(6): 270-275.

\section{How to cite this article:}

Bhagat Singh, Mukesh Kumar and Dhaka, A.K. 2018. Relationship of Temperature Based Meteorological Indices with Phenology and Yield Performance of Wheat as Influenced by Sowing Times. Int.J.Curr.Microbiol.App.Sci. 7(03): 230-241.

doi: https://doi.org/10.20546/ijcmas.2018.703.027 